\title{
Senate Gives Advice and Consent to Ratification of Four Bilateral Tax Treaties
}

doi:10.1017/ajil.2019.58

In July of 2019, the U.S. Senate gave advice and consent to protocols updating tax treaties with Spain, Switzerland, Japan, and Luxembourg, after a nearly decade-long period during which no tax treaties were approved by the Senate. This drought was primarily due to the privacy concerns of a single senator, Rand Paul of Kentucky, who deployed the Senate's procedural rules to increase the difficulty of the advice and consent process. Tax treaties with Hungary, Chile, and Poland, as well as a protocol to a multilateral tax convention, remained pending in the Senate Foreign Relations Committee as of mid-August of 2019.

Bilateral tax treaties typically focus on some combination of reducing double taxation and deterring tax avoidance. In the years leading up to 2011, the Senate generally gave its advice and consent to these treaties within a year or two of their signing. ${ }^{1}$ Senator Paul's opposition, which began shortly after he joined the Senate in 2011, changed this pattern. ${ }^{2}$

In a 2014 letter, Senator Paul explained that his concern with pending tax treaties stemmed from provisions that, in his view, increased the scope of authority of tax officials to share and ascertain taxpayer information and represented a departure from individual privacy rights:

the Senate Foreign Relations Committee, making it impossible for the President to unsign it until it is returned") (internal quotation marks and citations omitted).

${ }^{1}$ E.g., U.S. Senate Resolution of Advice and Consent to Ratification of the Tax Convention with Malta, 111th Cong., 156 Cong. Rec. S5976 (daily ed. July 15, 2010) (signed Aug. 8, 2008; advice and consent on July 15, 2010); U.S. Senate Resolution of Advice and Consent to Protocol Amending Tax Convention with New Zealand, 111 th Cong., 156 Cong. Rec. S5976 (daily ed. July 15, 2010) (signed Dec. 1, 2008; advice and consent on July 15, 2010); U.S. Senate Resolution of Advice and Consent to Ratification of the Protocol Amending Tax Convention with France, 111th Cong., 155 Cong. Rec. S12350-S12351 (daily ed. Dec. 3, 2009) (signed Jan. 13, 2009; advice and consent on Dec. 3, 2009); U.S. Senate Resolution of Advice and Consent to Ratification of the Protocol Amending 1980 Tax Convention with Canada, 110th Cong., 154 Cong. ReC. S9332 (daily ed. Sept. 23, 2008) (signed Sept. 21, 2007; advice and consent on Sept. 23, 2008); U.S. Senate Resolution of Advice and Consent to Ratification of the Tax Convention and Protocol with Bulgaria with Proposed Protocol of Amendment, 110th Cong., 154 Cong. Rec. S9332 (daily ed. Sept. 23, 2008) (signed Feb. 26, 2008; advice and consent on Sept. 23, 2008); U.S. Senate Resolution of Advice and Consent to Ratification of the Tax Convention with Iceland, 110th Cong., 154 Cong. Rec. S9332 (daily ed. Sept. 23, 2008) (signed Oct. 23, 2007; advice and consent on Sept. 23, 2008); U.S. Senate Resolution of Advice and Consent to Ratification of the Tax Convention with Belgium, 110th Cong., 153 Cong. Rec. S15706 (daily ed. Dec. 14, 2007) (signed Nov. 27, 2006; advice and consent on Dec. 14, 2007); U.S. Senate Resolution of Advice and Consent to Ratification of the Protocol Amending Tax Convention with Germany, 110th Cong., 153 Cong. ReC. S15706 (daily ed. Dec. 14, 2007) (signed June 1, 2006; advice and consent on Dec. 14, 2007); U.S. Senate Resolution of Advice and Consent to Ratification of the Protocol Amending Tax Convention with Denmark, 110th Cong., 153 Cong. REC. S14654 (daily ed. Nov. 16, 2007) (signed May 2, 2006; advice and consent on Nov. 16, 2007); U.S. Senate Resolution of Advice and Consent to Ratification of the Protocol Amending Tax Convention with Finland, 110th Cong., 153 Cong. Rec. S14654 (daily ed. Nov. 16, 2007) (signed May 31, 2006; advice and consent on Nov. 16, 2007).

${ }^{2}$ See Diane M. Ring, When International Tax Agreements Fail at Home: A U.S. Example, 41 Brook. J. INT'L L. 1185, 1197-207 (2016) (describing Paul's concerns and his method of delaying the treaties); see also Jim Tankersley, Senate Approves Tax Treaties for First Time in Decade, N.Y. Times (July 17, 2019), at https://www. nytimes.com/2019/07/17/business/tax-treaties-vote.html ("Mr. Paul has long objected to those informationsharing provisions on privacy grounds, and he succeeded for years in holding up approval of the treaties."). 
Previous tax treaties were more focused on information specific to suspicions of tax fraud while requiring that serious allegations of tax wrongdoing were grounded in evidence. However, these new bulk collection treaties demand Americans' records under a vague standard that allows the government to access personal financial information that "may be relevant" through information exchanges between the U.S. and foreign governments-a standard extended to other governments, as well. This new, much lower and ambiguous threshold allows the government to access bank records for hardly any reason at all.

I certainly do not condone tax cheats, but I can't support a law that endangers regular foreign investment and punishes every American in pursuit of a few tax cheats. Most importantly, I cannot support a bulk collection tax treaty that has complete disregard for the important protections provided to every American by the Fourth Amendment. ${ }^{3}$

Senator Paul also cited the potential for these tax treaties to lead to implementation of a recently passed domestic law which, in his view, was also problematic with respect to taxpayer privacy. ${ }^{4}$

Of the four tax treaties that recently received advice and consent, the earliest treaty (Luxembourg) was submitted to the Senate in 2010..$^{5}$ The following year, the Senate Foreign Relations Committee voted to send the protocol to the full Senate, but Senator Paul invoked a procedural rule to make it challenging for entire Senate to vote on this protocol. The usual process for bringing a treaty to a vote on the Senate floor requires the unanimous consent of the Senate. In a break from common practice, Senator Paul began registering objections to tax treaties that prevented such unanimous consent. ${ }^{6}$ While the Senate could have overridden Paul's request by voting in favor of cloture (a vote which would require sixty Senators in its favor), this could have led to delays in the other business of the Senate. If cloture occurs, Senate Rule XXII establishes that the issue in question "shall be the unfinished business to the exclusion of all other business until disposed of," which may amount to up to thirty hours of debate. ${ }^{7}$ Given the other considerations facing the Senate, its membership opted not to seek cloture on the tax treaties reported out favorably by the Senate Foreign Relations Committee between 2011 and 2018. ${ }^{8}$

In June of 2019, the Senate Foreign Relations Committee once again reported the protocols with Spain, Switzerland, Japan, and Luxembourg favorably out of committee. ${ }^{9}$ The U.S.

\footnotetext{
${ }^{3}$ Letter from Rand Paul, U.S. Senator, to Harry Reid, U.S. Senate Majority Leader (May 7, 2014), available at http://online.wsj.com/public/resources/documents/PaulLetter050714.pdf [https://perma.cc/5HT9-FPNP].

${ }^{4}$ Id.; see also Letter from Coalition of 23 Groups to Congress (Mar. 21, 2017), available at http://freedomand prosperity.org/files/2017-FATCA_repeal_coalition_ltr.pdf [https://perma.cc/GWW4-MLAU] (expressing concerns similar with respect to Paul's); see also John S. Wisiackas, Comment, Foreign Account Tax Compliance Act: What It Could Mean for the Future of Financial Privacy and International Law, 31 EmORY InT'L L. Rev. 585, 606 (2017) (noting that Senator Paul's court case against this domestic law was dismissed for lack of standing and that the underlying information sharing policies of this law have not been ruled unconstitutional to date).

${ }^{5}$ Protocol Amending Tax Convention with Luxembourg, S. Treaty Doc. No. 111-8 (2010).

6 See Ring, supra note 2, at 1205.

7 Standing Rules of the Senate, Rule XXII(2), S. Doc. No. 113-18 (2013), at https://www.rules.senate.gov/ rules-of-the-senate; Ring, supra note 2, at 1197-207.

${ }^{8}$ See Ring, supra note 2, at 1197-207.

9 Senate Committee on Foreign Relations, Chairman's Press Release, Four Tax Treaties Approved in Foreign Relations Committee Business Meeting (June 26, 2019), at https://www.foreign.senate.gov/press/chair/release/ four-tax-treaties-approved-in-foreign-relations-committee-business-meeting- (quoting the Chair, Senator Jim
} 
Chamber of Commerce and multiple U.S. corporations strongly supported their approval. ${ }^{10}$ On July 11, with the support of Senate Majority Leader Mitch McConnell, motions for cloture for all four treaties were brought to the Senate floor. ${ }^{11}$ On July 16, the Senate voted for cloture on the protocol with Spain by a vote of 94 to 1, with Paul casting the sole "no" vote. ${ }^{12}$ Following debate, the Senate then advised and consented to this protocol on the same day by a vote of 94 to 2, with the two "no" votes coming from Paul and Senator Mike Lee of Utah. ${ }^{13}$ Presumably following an understanding reached with Paul, the cloture motions were withdrawn on the other three treaties and unanimous consent was given for votes to be held with respect to them. ${ }^{14}$ On July 17 , these three treaties were approved by overwhelming majorities. ${ }^{15}$ As of mid-August 2019, none of the treaties have yet been ratified by the president.

During the debate over these treaties in the Senate, Paul was chided for his delaying tactics by McConnell who, like Paul, is a Republican Senator from Kentucky. McConnell remarked:

[T] he years of delays in getting these noncontroversial treaties ratified have cost American businesses that employ American workers millions and millions of dollars.

$\cdots$

I was curious to hear one colleague of ours come to the floor yesterday and passionately argue against what I have done as majority leader to support these agreements. . .

At every step, executive branch officials and Senate colleagues have tried to engage his concerns in good faith. But for 6 years in the case of the Spain treaty, 8 years with respect to Switzerland, and 9 years with respect to Luxembourg, he was unable to persuade anyone-over 9 years. In all of that time, no one was persuaded, partly because the changes he demanded don't solve a real problem, partly because they would have forced reopening the treaties for even more negotiations, and partly because everybody else was actually listening to the job creators who have been pleading with us for years to get this millstone

Risch, as saying: "[T]hese treaties have languished and awaited ratification for nearly a decade, and are incredibly important to our own citizens. I appreciate Leader McConnell's commitment to moving these treaties. I look forward to working with him to see that they are ratified by the full Senate.").

${ }^{10}$ See, e.g., Letter from Business Roundtable et al. to James Risch, Chairman, Senate Comm. on Foreign Relations (Apr. 11, 2019), available at https:/www.semiconductors.org/wp-content/uploads/2019/04/2019Trade-Association-Letter-on-Tax-Treaties-to-all-Senate-Leadership-Risch-Letter-Final.pdf [https://perma.cc/ SQ5U-QJEV]; Letter from Neil L. Bradley, Exec. Vice President, Chamber of Commerce of the United States, to James E. Risch \& Bob Menendez, Senate Comm. on Foreign Relations (June 20, 2019), available at https://www.uschamber.com/letters-congress/us-chamber-letter-tax-treaties [https://perma.cc/PHU2-FHAB].

${ }^{11}$ 116th Cong., 165 Cong. ReC. S4795-S4797 (daily ed. July 11, 2019).

12 116th Cong., 165 Cong. Rec. S4847 (daily ed. July 16, 2019).

${ }^{13}$ U.S. Senate Resolution of Advice and Consent to Protocol Amending Tax Convention with Spain, 116th Cong., 165 Cong. Rec. S4850 (daily ed. July 16, 2019).

${ }^{14} 165$ CONG. REC. S4795-S4797 Supra note 12 (statement of Sen. Risch and the noted lack of objection to his request for unanimous consent). Senator Risch also noted that the Senate would have an opportunity to vote on an amendment proposed by Paul to the resolution of advice and consent for the Spain protocol. Id. The amendment was rejected by an overwhelming majority. $116^{\text {th }}$ Cong., 165 Cong. REC. S4849 (daily ed. July 16, 2019) (rejecting Paul's proposed amendment, with the vote being four in favor and ninety-two against).

15 116th Cong., 165 ConG. REC. S4875-S4878 (daily ed. July 17, 2019) (including the roll call for the treaties, which passed 95-2 (Japan), 95-2 (Switzerland), and 93-3 (Luxembourg)). The "no" votes on the treaties were Paul and Lee and, for the Luxembourg treaty, Senator Dick Durbin of Illinois. Id. Durbin had previously expressed skepticism about the importance of the Luxembourg treaty measured against other legislative priorities. 116th Cong., 165 Cong. Rec. S4830 (daily ed. July 16, 2019) (statement of Sen. Durbin). 
off their necks. There were 9 years -9 years of rejecting reasonable counteroffers and accommodations, 9 years of working to hold up these treaties and trying to sell the Obama administration, the Trump administration, and his Senate colleagues on an off-the-wall story that failed to persuade anyone.

Look, I am a patient man, but my patience is not inexhaustible. After unanimous consent was denied on multiple occasions, I determined, after consulting with the Treasury Secretary and the Chairman of the Foreign Relations Committee, that I would prepare to file cloture on these tax protocols. . .

$\cdots$

Year after year, money that could have been immediately used to hire Americans or make new investments had to either be frozen up or handed over in duplicate taxes — all in large part because one of our colleagues could not accept that one single senator who hasn't persuaded his fellow Members is not entitled to singlehandedly rewrite international treaties. $^{16}$

Following the passage of these four tax protocols, the Senate continues to have before it bilateral tax treaties with Hungary, Chile, and Poland, as well as a protocol to a multilateral tax treaty. ${ }^{17}$ All of these treaties had been reported favorably out by the Senate Foreign Relations Committee in prior years, ${ }^{18}$ only to fail to receive floor votes and therefore be returned to the Committee at the end of the legislative session. The three bilateral treaties remain stalled in the Senate Foreign Relations Committee, apparently due in part to a Treasury Department request for the addition of a new reservation to each treaty. ${ }^{19}$ It remains to be seen when these treaties will advance out of committee and, if so, whether they will receive floor votes.

16 116th Cong., 165 Cong. ReC. S4872-S4873 (daily ed. July 17, 2019) (statement of Sen. McConnell).

${ }^{17}$ See U.S. Dep't of State, Treaties Pending in the Senate (July 17, 2019), at https://www.state.gov/treaties-pend ing-in-the-senate [https://perma.cc/FF4Z-2ZDV].

${ }^{18}$ For the earlier actions of the Senate Foreign Relations Committee reporting these treaties out of committee, see Tax Convention with Hungary, S. ExeC. ReP. No. 112-4 (2011), at https://www.congress.gov/congressionalreport/112th-congress/executive-report/4 [https://perma.cc/HM2P-GDDW]; Tax Convention with Chile, S. ExEC. Rep. No. 113-9 (2014), at https:/www.congress.gov/congressional-report/113th-congress/executivereport/9 [https://perma.cc/PG53-Z529]; Tax Convention with Poland, S. ExEc. ReP. No. 113-11 (2014), at https://www.congress.gov/congressional-report/113th-congress/executive-report/11 [https://perma.cc/GE35BUVC]; Protocol Amending Multilateral Convention on Mutual Administrative Assistance in Tax Matters, S. EXEC. REP. 113-8 (2014), at https://www.congress.gov/congressional-report/113th-congress/executive-report/8.

19 See Letter from Robert Menendez, Ranking Member, Senate Comm. on Foreign Relations, to Steven T. Mnuchin, Sec'y, U.S. Dep't Treasury (June 11, 2019), available at https:/www.foreign.senate.gov/ imo/media/doc/06-11-19\%20RM\%20letter\%20to\%20Mnuchin\%20re\%20Tax\%20Treaties.pdf [https://perma. cc/4PYE-LXHJ] (expressing concern and confusion about a reservation the Treasury Department sought to add concerning the "base erosion anti-abuse tax" and enquiring whether this addition would require the international renegotiation of these treaties). 